\title{
Rapid genetically modified organism (GMO) screening of various food products and animal feeds using multiplex polymerase chain reaction (PCR)
}

\author{
${ }^{1 *}$ Lisha, V., ${ }^{1}$ New, C.Y., ${ }^{2}$ Nishibuchi, M. and ${ }^{1}$ Son, R. \\ ${ }^{I}$ Department of Food Science, Faculty of Food Science and Technology, Universiti Putra Malaysia \\ (UPM), 43400 UPM Serdang, Selangor Darul Ehsan, Malaysia \\ ${ }^{2}$ Center for Southeast Asia Studies, Kyoto University, Kyoto 606-8501, Japan
}

\begin{abstract}
Article history:
Received: 4 January 2017 Received in revised form: 14 January 2017 Accepted: 15 January 2017 Available online: 18 January 2017
\end{abstract}

Keywords:

Genetically modified organisms (GMO) Food products

Animal feed

Detection

Multiplex PCR

Soy

Maize

DOI:

http://doi.org/10.26656/ fr.2017.1.001

\begin{abstract}
The revolution of agriculture through biotechnology have produced large-scale of genetically modified crops which brought up a controversy on the safety usage of genetically modified organisms (GMOs). It has been implemented globally that all GMO products and its derived ingredients should have regulations on the usage and labelling. Thus, it is necessary to develop methods that allow rapid screening of GMO products to comply with the regulations. This study employed a reliable and flexible multiplex polymerase chain reaction (PCR) method for the rapid detection of transgenic elements in genetically modified soy and maize along with the soybean LECTIN gene and maize ZEIN gene respectively. The selected four common transgenic elements were $35 \mathrm{~S}$ promoter (35S); Agrobacterium tumefaciens nopaline synthase terminator (NOS); 5-enolypyruvylshikimate-3-phosphate synthase (epsps) gene; and CrylAb delta-endotoxin (crylAb) gene. Optimization of the multiplex PCR methods were carried out by using 1\% Roundup Ready ${ }^{\mathrm{TM}}$ Soybean (RRS) as the certified reference material for soybean that produced fourplex PCR method detecting 35S promoter, NOS terminator, epsps gene and soybean LECTIN gene and by using 1\% MON810 as the certified reference material for maize that produced triplex PCR method detecting $35 \mathrm{~S}$ promoter, cry $1 \mathrm{Ab}$ gene and maize ZEIN gene prior to screening of the GMO traits in various food products and animal feeds. $1 / 9(11.1 \%)$ of the animal feed contained maize and $1 / 15(6.7 \%)$ of the soybean food products showed positive results for the detection of GMO transgenic gene. None of the maize food products showed positive results for GMO transgenic gene. In total, approximately $4 \%$ of the food products and animal feed were positive as GMO. This indicated GMOs have not widely entered the food chain. However, it is necessary to have an appropriate screening method due to GMOs' unknown potential risk to humans and to animals. This rapid screening method will provide leverage in terms of being economically wise, time saving and reliable.
\end{abstract}

\section{Introduction}

Genetically modified organisms (GMOs) are an organism where the genetic material has been altered using genetic engineering techniques known as recombinant deoxyribonucleic acid (DNA) technology. The gene technology had resulted in benefitting the world's fastest growing population by ensuring sustainable food production (Latifah Amin et al., 2011). The most common genetically modified (GM) plants are herbicide-tolerant and insectresistant soybeans, maize, cotton and rapeseed. In recent years, both planting area and varieties of GM crops have been continuously increased (James, 2014). Global spread of GM plants largely enhanced the share of GMOs in the worldwide distributed and commercialized plants, seeds, grains, food, and feed. International service for the acquisition of Agribiotech Application (ISAAA) reported that the planting of GM crops in the world is increasing over the years, from 134 million hectares in 2009 to 170.3 million hectares in 2012 (James, 2007). In Malaysia, the government is forecasted to be an active venture in the biotechnology industry by 2020 to solving the global crisis. In fact, Malaysia is undergoing a huge amount of GM food imported from the United States, the market leader of GM foods with 69.5 million hectares of areas planted with GM crops. The two most cultivated GM plants globally are the biotech soybean $(60 \%)$ of the global biotech area and biotech maize (23\% of the global area) (James, 2003). Other GM plants include cotton and oilseed 
rape was reported to have $27 \%$ and $19 \%$ of the total global cultivation identified as GM (Food Standards Agency, 2005).

According to Ahmed (2002), most of the currently available GMOs worldwide contained any of three genetic elements: the cauliflower mosaic virus (CaMV) 35S promoter, the nopalin synthase (NOS) terminator or the kanamycin-resistance marker gene (nptII). In addition, the introduction of herbicide resistance gene, 5-enolpyruvylshikimate3-phosphate synthase (epsps) and insect resistance, crylAb Bt gene into plant genome are the current dominant traits in GM crops (Hemmer, 1997; James et al., 2003).

The detection of GMOs in food is an important issue for all the subjects involved in raw material control, food industry, and distribution. As the number of GMOs authorized in the European Union (EU) increased during the past few years, Malaysia has enforced the necessity of labelling of food derived from GMO to comply with the Novel Food Regulation (EC/258/97, EC/1139/98, EC/49/2000, $\mathrm{EC} / 50 / 2000$ and $\mathrm{EC} / 1829 / 2003)$ and to abide to the Malaysian Food Act 1983 and Regulations 1985. This brings the need to develop methods that allow rapid screening of products for GMO traits. Polymerase Chain Reaction (PCR) had been relied on heavily for GMO detection methods apart from immunological method and sensors. As such, multiplex PCR has become the prime tool for GM detection (Xu et $a l ., 2007)$ which initiated this study to optimize a multiplex PCR detection method for simultaneous detection of GMO transgenic elements and to screen for GMO traits in various food products and animal feed.

\section{Materials and methods}

\subsection{Samples and reference materials}

Forty-one food products and nine animal feed samples containing soybean and maize were collected randomly from local markets and supermarkets around Wilayah Persekutuan Kuala Lumpur, Malaysia. Specifically, twenty-six food products were maize and maize products while fifteen food products were soybean and soybean products. All the animal feed contained maize in its ingredient were selected. 1\% Roundup Ready ${ }^{\mathrm{TM}}$ Soybean (RRS) and $1 \%$ MON810 were used as the certified reference materials (CRM) for soybean and maize respectively. The certified reference materials were purchased from Sigma Aldrich, United Kingdom.

\subsection{Cetyltrimethylammonium bromide (CTAB) deoxyribonucleic acid (DNA) extraction}

All certified reference materials, food products and animal feed samples were subjected to CTAB DNA extraction, a method proposed by the European Committee for Standardization (CEN) in 2002 to extract genomic DNA from food samples for the detection of genetically modified foods. Briefly, a portion of the samples was taken and blended into granulated powder. $200 \mathrm{mg}$ of the blended sample was weighed and made into a paste with $500 \mu 1$ of freshly made CTAB buffer containing $0.02 \mathrm{~g}$ of Polyvinylpyrolidone 40 (PVP-40) (Nacalai tesque, Japan) and $2.5 \mu \mathrm{l}$ of $\beta$-mercaptoethanol (Nacalai tesque, Japan). The paste was transferred into a clean $1.5 \mathrm{ml}$ microcentrifuge tubes and incubated at $55^{\circ} \mathrm{C}$ for 15 minutes. The samples were then centrifuged at $12,000 \mathrm{rpm}$ for 5 minutes. The supernatant is transferred to another clean $1.5 \mathrm{ml}$ microcentrifuge tubes and added with $250 \mu \mathrm{l}$ chloroform: isoamyl alcohol 24: 1 (Sigma Aldrich, United Kingdom). The tubes were inverted gently and centrifuged for 1 minute at 13,000 rpm. The upper phase layer was transferred into a new $1.5 \mathrm{ml}$ microcentrifuge tube and added with $50 \mu 1$ of $7.5 \mathrm{M}$ ammonium acetate (Nacalai tesque, Japan) and $500 \mu 1$ ice cold absolute ethanol (Merck, Germany). The tubes were inverted slowly before sitting in $-20^{\circ} \mathrm{C}$ freezer overnight. The tubes were centrifuged for 1 minute at maximum speed and the supernatant was discarded. The leftover pellet was washed with $700 \mu 1$ of $70 \%$ ice cold ethanol (Merck, Germany). The washing was repeated twice before drying the pellet for 15 minutes on a hot plate at $55^{\circ} \mathrm{C}$. The pellet was then dissolved with $200 \mu \mathrm{l}$ sterile distilled water, incubated at $65^{\circ} \mathrm{C}$ for 20 minutes before storing the them at $4^{\circ} \mathrm{C}$ for further use.

\subsection{PCR analysis}

Optimization was carried out by performing uniplex first, followed by multiplex. Different parameters such as PCR buffer concentration $(1 \mathrm{X}-1.5 \mathrm{X})$, primer concentration $(0.1-1.0 \mu \mathrm{M})$, magnesium chloride $\left(\mathrm{MgCl}_{2}\right)$ concentration (1.5 - $3.5 \mathrm{mM})$, number of cycles $(35-45$ cycles), annealing temperature $\left(60-72^{\circ} \mathrm{C}\right)$, elongation time $(30-45$ seconds) and Taq polymerase $(1.0-1.5 \mathrm{U})$ were tested during optimization. All reagents were purchased from Promega, USA except for the primers which were produced by Sigma Aldrich, Malaysia. Table 1 shows the primers used to detect the GMO transgenic genes.

The triplex PCR method for maize was performed by mixing $2 \mu \mathrm{l}$ of genomic DNA, 1.5X PCR Green 
Table 1. Primers used to detect the GMO transgenic elements.

\begin{tabular}{|c|c|c|c|c|}
\hline Target Gene & Primer Pair & Sequences (5' - 3') & Amplicon (bp) & Reference \\
\hline \multirow[t]{2}{*}{ LECTIN } & LECT - F & ACGGCACCCCAAAACCCTCG & \multirow[t]{2}{*}{101} & \multirow[t]{2}{*}{ Kutateladze et al. (2013) } \\
\hline & LECT - R & GGAAGCGGCGAAGCTGGCAA & & \\
\hline \multirow[t]{2}{*}{ ZEIN } & ZEIN - F & ACACCACCGACCATGGCAGC & \multirow[t]{2}{*}{102} & \multirow[t]{2}{*}{ Gabriadze et al. (2014) } \\
\hline & ZEIN - R & TGGTGGCAAGTGCGCTGGAA & & \\
\hline \multirow[t]{2}{*}{ epsps } & EPSPS - F & ACCGGCCTCATCCTGACGCT & \multirow[t]{2}{*}{256} & \multirow[t]{2}{*}{ Datukishvili et al. (2015) } \\
\hline & EPSPS - R & CCGAGAGGCGGTCGCTTTCC & & \\
\hline \multirow[t]{2}{*}{ crylAb } & cryl - F & GCACCTCCGTGGTGAAGGGC & \multirow[t]{2}{*}{258} & \multirow[t]{2}{*}{ Datukishvili et al. (2015) } \\
\hline & cry1 - R & AACCCACGGTGCGGAAGCTG & & \\
\hline \multirow[t]{2}{*}{$35 \mathrm{~S}$ promoter } & P35S - F & TGCCTCTGCCGACAGTGGTC & \multirow[t]{2}{*}{83} & \multirow[t]{2}{*}{ Trapmann et al. (2002) } \\
\hline & P35S - R & AAGACGTGGTTGGAACGTCTTC & & \\
\hline \multirow{2}{*}{$\begin{array}{l}\text { NOS } \\
\text { terminator }\end{array}$} & NOS - F & GGTACCGGATCCAATTCCCGATCGTT & \multirow[t]{2}{*}{224} & \multirow[t]{2}{*}{ Datukishvili et al. (2015) } \\
\hline & NOS - R & CGCGCTATATTTTGTTTTCTATCGCGT & & \\
\hline
\end{tabular}

Buffer, $2.0 \mathrm{mM} \mathrm{MgCl}{ }_{2}, 0.2 \mathrm{mM}$ dNTP mix, $0.3 \mu \mathrm{M}$ ZEIN and cry 1 primers, $1.0 \mu \mathrm{M}$ P35S primers, 1.25 $\mathrm{U}$ of Taq polymerase and topped-up with sterile distilled water to a final volume of $25 \mu 1$. As for the fourplex PCR method for soybean; $2 \mu$ of genomic DNA, 1.5X PCR Green Buffer, $3.5 \mathrm{mM} \mathrm{MgCl}, 0.2$ $\mathrm{mM}$ dNTP mix, $0.2 \mu \mathrm{M}$ EPSPS primers, $1.0 \mu \mathrm{M}$ P35S primers, $0.1 \mu \mathrm{M}$ LECT primers, $1.25 \mathrm{U}$ of Taq polymerase and topped-up with sterile distilled water to a final volume of $25 \mu 1$.

Both maize and soybean shared the same optimized multiplex PCR conditions. All PCR tubes were subjected to pre-denaturation at $95^{\circ} \mathrm{C}$ for 5 minutes, 40 cycles of denaturation at $95^{\circ} \mathrm{C}$ for 30 seconds, annealing at $65.5^{\circ} \mathrm{C}$ for 30 seconds, extension at $72^{\circ} \mathrm{C}$ for 30 seconds, and final extension at $72^{\circ} \mathrm{C}$ for 7 minutes before holding at $4{ }^{\circ} \mathrm{C}$. PCR end products were separated via $2.0 \%$ agarose gel electrophoresis at $60 \mathrm{~V}$ for 80 minutes and visualized under Gel Documentation System (Syngene, USA) after staining with $0.5 \mu \mathrm{g} / \mathrm{ml}$ of ethidium bromide.

\section{Results and discussion}

The multiplex PCR methods for both soybean and maize were successfully optimized. The triplex PCR method for maize for the simultaneous detection of two GMO transgenic elements along with the maizespecific amplicon were as shown in Figure 1 based on the end products identified using the molecular weight marker 100 bp DNA ladder (Promega, USA). The identified amplicons were $35 \mathrm{~S}$ promoter ( $83 \mathrm{bp}$ ), $c r y 1 A b$ transgenic gene (258 bp) and the maize ZEIN gene (102 bp). While, the fourplex PCR method for soybean for simultaneous identification of three GMO transgenic elements as shown in Figure 2 together with the soybean-specific amplicon (Kutateladze et al., 2013). The identified amplicons were 35S promoter ( $83 \mathrm{bp}$ ), NOS terminator (224 bp), epsps transgenic gene (256 bp) and the soybean LECTIN gene (101 bp).

During the optimization process, it was noted that the primer pairs were sensitive towards the slight change of the annealing temperature $\left(T_{a}\right)$ although most of the primer pairs had close melting temperatures $\left(\mathrm{T}_{\mathrm{m}}\right)$. We experienced missing bands of the targeted end products, even with only $1^{\circ} \mathrm{C}$ change away from the suggested $\mathrm{T}_{\mathrm{a}}$. To have this resolved, gradient PCR was carried out to identify the optimum temperature. It should be noted that most thermal cycler models do not allow minor changes $\left(<1^{\circ} \mathrm{C}\right)$ in the temperature gradient which resulted us to pick out the best yield amplicon visually and run trial-errors. Also, thermal cycler models that are less likely to generate a uniform temperature gradient across the heating block will intervene the process and cause error (Roux, 2009).

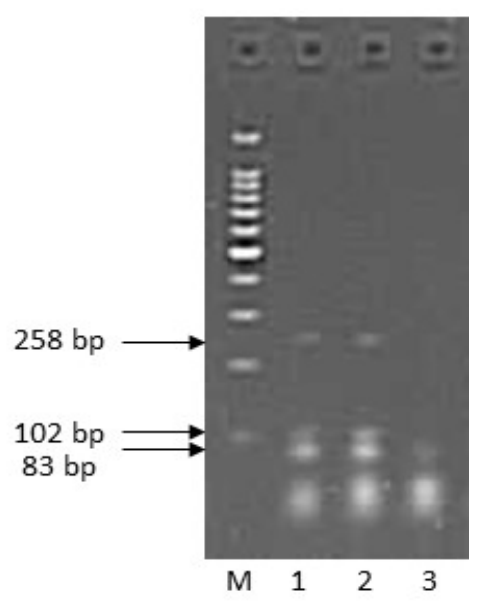

Figure 1. Optimized triplex PCR detection for maize certified reference material, $1 \% \mathrm{MON} 810 . \mathrm{M}$ is the molecular weight marker (Promega 100 bp DNA ladder). Lane $1-2$ shows the maize certified reference material, $1 \% \mathrm{MON} 810$ (crylAb gene at $258 \mathrm{bp}$; maize ZEIN gene at $102 \mathrm{bp}$; and 35S promoter at $83 \mathrm{bp}$ ). Lane 3 shows blank (negative control). 


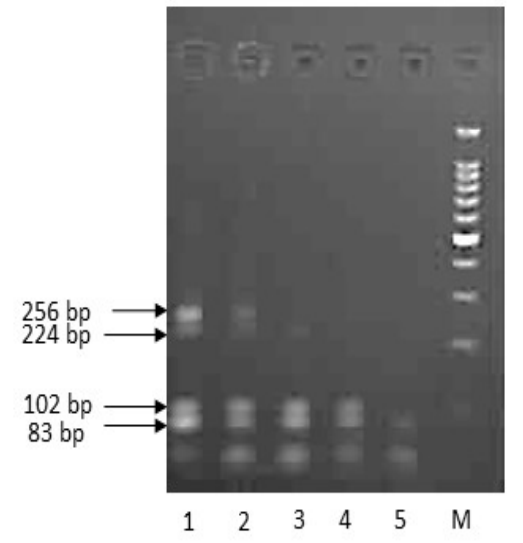

Figure 2. Optimized fourplex PCR detection for soybean certified reference material, 1\% Roundup Ready ${ }^{\mathrm{TM}}$ Soybean (RRS). Lane $1-4$ shows the soybean certified reference material, $1 \%$ Roundup Ready ${ }^{\mathrm{TM}}$ Soybean (RRS) with the following Lane 1 -2 : Without dilution; Lane 3-4: 100-fold dilution (epsps gene at $256 \mathrm{bp}$; NOS terminator at $224 \mathrm{bp}$; soybean LECTIN gene at 101 $\mathrm{bp}$; and $35 \mathrm{~S}$ promoter at $83 \mathrm{bp}$ ). Lane 5 shows blank (negative control). $\mathrm{M}$ is the molecular weight marker (Promega $100 \mathrm{bp}$ DNA ladder).

A rule of thumb in PCR optimization stated that the best approximation of the $\mathrm{T}_{\mathrm{a}}$ of the primers had to be $\pm 5^{\circ} \mathrm{C}$ of the $\mathrm{T}_{\mathrm{m}}$. But in practice, the $\mathrm{T}_{\mathrm{m}}$ is variously affected by the individual buffer components, the primer and the template concentrations in which resulted that any calculated $\mathrm{T}_{\mathrm{m}}$ should be regarded as an approximation (Roux, 2009). He et al. (1994) also noted that some of the primers are refractory to optimization for some reasons that are not entirely apparent. This was also experienced during the optimization process, particularly the $35 \mathrm{~S}$ promoter primer pairs and NOS terminator primer pairs, although we adopt primers from other researchers and did not do any primer design. The adopted primers were reportedly working effectively. However, the results could be different due to thermal cycler models and reagents used. Time and cost will be a disadvantage to proceed with these primers and therefore a second set of primers was purchased which yield favourable results.

Based on Figure 1 and 2, faint PCR end products were observed, which was likely due to DNA degradation even after the optimum $\mathrm{T}_{\mathrm{a}}$ had been selected. The applicability of DNA-based methods largely depends on the quality and quantity of the DNA (Gryson, 2010). The CTAB DNA extraction method can extract pure DNA of the high molecular weight from plants and is an efficient technique for a widespread range of plant materials and plant derived foods by providing a good separation of DNA from polysaccharides (Jasbeer et al., 2008). However, the storage condition $\left(4^{\circ} \mathrm{C}\right)$ of the DNA templates will cause the DNA to degrade over time due to nuclease contamination caused by microbial contamination. Repeated freeze-thaw cycles of DNA stored at lower temperatures might also affect the DNA stability and may shear the DNA. Other possibilities could be due to the presence of PCR inhibitors and/or DNA degrading enzymes.

All PCR parameters tested gave different yields. Worth noting would be the increment of cycles (additional 5 cycles) which caused unspecific binding. We referred to many guides and troubleshooting which noted that we should increase the number of cycles used if faint bands produced (Bio-Rad, 2017). As a result, we retained back to the original number of cycles. The other parameters were observed to have minimal effects on the yield. The final optimized methods were re-run for two to three times to ensure the reproducibility before the screening of the various food products and animal feeds.

The GMO screening results of the various food products and animal feed for maize and soybean are as shown in Table 2 and Table 3 respectively. Figure 3 and 4 shows the multiplex PCR screening results for maize and soybean respectively. 5/26 (19.2\%) maize food products and 6/9 (66.7\%) of animal feed were identified to yield the specifically maize ZEIN amplicon. 11/15 (73.3\%) of the soybean food product showed positive bands for the soybeanspecific amplicon. The presence of the plant-specific gene in the food products and animal feed concluded that the food products and animal feed were made or contained the plant as its major ingredient listed in the ingredient list. However, the undetectable plantspecific gene in samples were due to food processing. Certain important food-processing conditions such as temperature and $\mathrm{pH}$ could lead to the degradation of the DNA, rendering PCR analysis impossible (Gryson, 2010). For example, heavily processed foods such as snacks and highly fermented products like soy sauce, which were coherent with our findings.

Table 2. Detected GMO transgenic elements in food products and animal feed that contained maize.

\begin{tabular}{|c|c|c|c|c|}
\hline \multirow[b]{2}{*}{ Products } & \multirow{2}{*}{$\begin{array}{l}\text { Number of } \\
\text { Samples } \\
\text { (n) }\end{array}$} & \multicolumn{3}{|c|}{ Target Genes [n (\%)] } \\
\hline & & ZEIN & cry $1 \mathrm{Ab}$ & $\begin{array}{c}35 \mathrm{~S} \\
\text { Promoter }\end{array}$ \\
\hline $\begin{array}{l}\text { Maize (Food } \\
\text { Products) }\end{array}$ & 26 & $\begin{array}{c}5 \\
(19.2 \%)\end{array}$ & $\begin{array}{c}0 \\
(0.0 \%)\end{array}$ & $\begin{array}{c}6 \\
(23.0 \%)\end{array}$ \\
\hline Animal Feed & 9 & $\begin{array}{c}6 \\
(66.7 \%)\end{array}$ & $\begin{array}{c}1 \\
(11.1 \%)\end{array}$ & $\begin{array}{c}9 \\
(34.6 \%)\end{array}$ \\
\hline Total & 35 & $\begin{array}{c}11 \\
(31.4 \%)\end{array}$ & $\begin{array}{c}1 \\
(2.9 \%)\end{array}$ & $\begin{array}{c}15 \\
(42.9 \%)\end{array}$ \\
\hline
\end{tabular}


Table 3. Detected GMO transgenic elements in soybean food products $(n=15)$.

\begin{tabular}{lcccc} 
& \multicolumn{4}{c}{ Target Genes [n (\%)] } \\
\cline { 2 - 4 } & $\begin{array}{c}35 \mathrm{~S} \\
\text { promoter }\end{array}$ & LECTIN & epsps & $\begin{array}{c}\text { NOS } \\
\text { terminator }\end{array}$ \\
\hline $\begin{array}{l}\text { Soybean } \\
\text { (Food }\end{array}$ & 15 & 11 & $1(6.7 \%)$ & $1(6.7 \%)$ \\
Products) & $(100 \%)$ & $(73.3 \%)$ & & \\
\hline
\end{tabular}

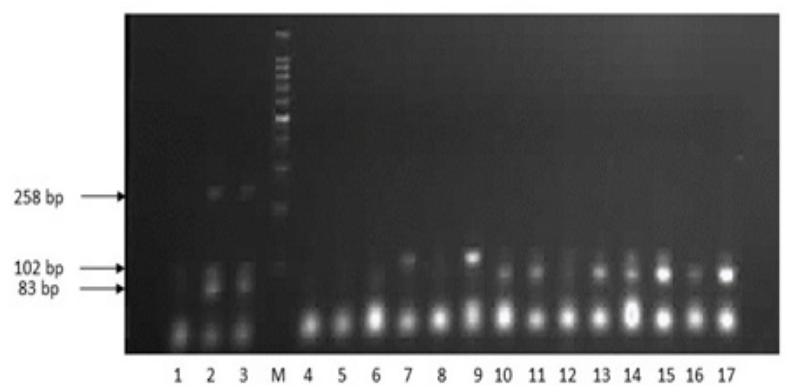

Figure 3. A representative amplification of the triplex PCR GMO screening of maize. Lane 1 shows blank (negative control). Lane $2-3$ shows the detection of maize certified reference material $1 \%$ MON810 (crylAb gene at $258 \mathrm{bp}$; maize ZEIN gene at 102 $\mathrm{bp} ; 35 \mathrm{~S}$ promoter at $83 \mathrm{bp}$ ). $\mathrm{M}$ is the molecular weight markers (Promega 100 bp DNA ladder). Lane $4-17$ are samples.

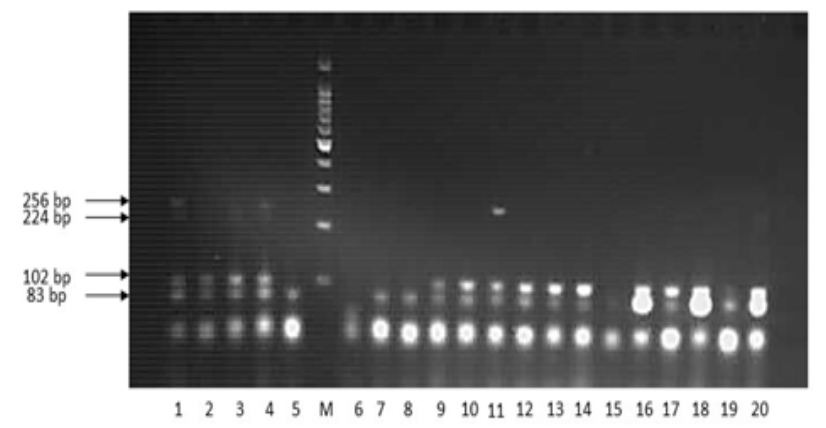

Figure 4. A representative amplification of the fourplex PCR GMO screening of soybean. Lane $1-4$ shows the soybean certified reference material, 1\% Roundup Ready ${ }^{\mathrm{TM}}$ Soybean (RRS) (epsps gene at $256 \mathrm{bp}$; NOS terminator at $224 \mathrm{bp}$; soybean LECTIN gene at $102 \mathrm{bp} ; 35 \mathrm{~S}$ promoter gene at $83 \mathrm{bp}$ ). Lane 5 shows blank (negative control). $\mathrm{M}$ is the molecular weight markers (Promega 100 bp DNA ladder). Lane 6-20 are the food product samples that contained soybean.

Overall, 6/26 (23.0\%) food products containing maize were positive with at least one GMO transgenic element while all animal feed products contained at least one positive GMO transgenic element. Similarly, all soybean food products positive for at least one GMO transgenic element. This indicated that the wide-spread of the GMO transgenic elements which was detectable in the food products and animal feed. The $35 \mathrm{~S}$ promoter is highly detectable in the food products and animal feed (Table 1 and 2) which is due to its natural presence in Caulimovirus, the source of CaMV 35S promoter that naturally infects plants, especially cabbage family. A positive test for this promoter is not always conclusive and should be confirmed with further PCR test to amplify the specific transgenic genes (Brandner, 2002) which supports the reason why multiplex PCR was selected as the prime tool for GMO detection (Xu et al., 2007). Fewer reactions are needed and most importantly, the method saves time and reduces costs (James et al., 2003). As for the NOS terminator that was detectable in soybean food products showed that one sample $(6.7 \%)$ was positive. The NOS terminator derived from Agrobacterium tumefaciens was the commonly used terminator and it is naturally present in bacteria. Thus, it was inferred that the genetically modified material present had potentially been due to the natural presence of these microbes. One animal feed sample and one soybean food product (Table 2 and 3) was detected to be positive GMO via presence of the GMO transgenic genes amplicons. The total food products and animal feed $(n=50)$ positive to be identified as GMO was approximately $4 \%$.

The results substantially marked that GMOs had entered the food chain but not in a large scale. Theoretically, the consumption of GM foods that contained the genetically engineered DNA will be digested without any adverse consequences which is similar to the DNA of the non-GM crops. Yet, the public is still concern of the unknown risk of GMOs to humans and animals which sparked controversial ideas of GMO. In 2000, Food and Drug Administration recalled 300 supermarket and restaurant products made with StarLink ${ }^{\mathrm{TM}}$ corn produced by Aventis, USA, citing that the product contains Cry9C gene, which protects the plants against insect pests. The Cry9C protein produced in the modified corn was heat stable and resistant to stomach acids and enzymes; all characteristics of human allergens and was given a stipulation by the Environmental Protection Agency that the product was not for human consumption. However, the failure of Aventis to keep StarLink ${ }^{\mathrm{TM}}$ corn separated from nongenetically modified corn and thus entering the market (USDA, 2000). Along the way, many people argued that GMO food comes with risks which include exposure to possible allergens and toxins, harm to the environment, antibiotic resistance, and the spread of introduced genes to non-target plants by out crossing and pollen drift (Obrycki, 2001).

GM crops continue to be fed to farm animals on a large scale (Friends of the Earth, 2006). Animal feed had a high possibility of having GMO traits (as shown in the results) due to these two genetically engineered crops are major components of animal feed together with oilseed rape and cotton seeds. The Council for Agricultural Science and Technology (CAST, 2006) 
provided substantial data that stated that well over $95 \%$ of the products from animals fed GM crops are found in the market today. Our study indicated that only one sample was detected positive with transgenic gene while the rest were non-detectable which could be due to high processing and DNA degradation. Nevertheless, it should not be regarded as a threat as GM-feed had no impact on the livestock health. According to Van Eenennaam and Young (2014), the available data for health and production parameters across commercial poultry, dairy, beef and hogs showed no significant deleterious health with the consumption of GMO animal feed. Wellestablished data have shown that it is not possible to detect differences in the nutritional profiles of milk, meat and eggs from animals fed with GM feed versus animals that have consumed non-GM feed and there was no reliable traces of GM DNA or protein detected in products from GM-fed animals (Van Eenennaam and Young, 2016).

But then again, the reports on GMO food that could produce proteins triggering allergic reactions in humans made GMO food a food safety issue. Public awareness had begun to increase on this issue. Some countries have adopted labelling regulations partially due to consumers' pressure and public demand (Matsuoka et al., 2002) and having to ensure that the consumers are well-informed of what kind of food they eat. Such regulations necessitate appropriate techniques to identify the presence or absence of genetic modification so food can be labelled properly (Zimmermann, 1998). At the July 8, 2014, the Ministry of Health, Malaysia had begun to enforce the regulations pertaining to labelling of GMOs in food and feed after the Biosafety Bill was approved by Parliament in July 2007 (Jasbeer et al., 2008). A 3.0\% GMO labelling threshold has been approved. Although there is enforcement, however many manufacturers in agriculture and food production are yet to implement the regulations. Malaysian Food Act 1983 and Regulations 1985 had stated that any ingredient that are genetically modified, depending on its composition should be stated on the label. Many food products that are sold in Malaysia are yet to have this label present on the food labelling which could be due to the negligible amount of GMO in its ingredient or costly appropriate techniques in identifying. The multiplex PCR optimized in this research study could play a part in providing the appropriate techniques for rapid and cost-effective GMO screening for most manufacturers.

Despite the controversy, GMO food was designed to resolve food security issues - to make food available to the population in safe condition and nutritious due to our ever-growing population and insufficient food to feed everyone. Most of the transgenic genes incorporated were to control insect pests and weeds; to fight against virus and to enhance fresh market value of food by improving the food quality through the increase of nutritional content. However, the necessity to have proper labelling through appropriate identification techniques is important to protect consumers' right and to ensure food safety.

\section{Acknowledgement}

The research work was funded by Kakenhi Grant-in-Aid for Scientific Research (KAKENHI 24249038), Japan Society for the Promotion of Sciences and grant-in-aid of Ministry of Health, Labour and Welfare, Japan and in part Fundamental Research Grant Project (FRGS/1/2014/SG05/ UPM/01/2/5524559) from the Ministry of Education, Malaysia.

\section{References}

Ahmed, F. E. (2002). Detection of genetically modified organisms in foods. Trends in Biotechnology, 20(5), 215-223.

Bio-Rad (2017). PCR Troubleshooting. Retrieved on January 6, 2017 from Bio-Rad website: http://www. bio-rad.com/en-sg/applications-technologies/pcrtroubleshooting\#gel1

Brandner, D.L. (2002). PCR-Based detection of genetically modified foods. In O'Donnell, M.A. (Ed.) Tested studies for laboratory teaching. Proceedings of the 23rd Workshop/Conference of the Association for Biology Laboratory Education (ABLE), p. 6984. Madison, United States: Madison Area Technical College.

CEN. (2002). Foodstuffs-methods of analysis for the detection of genetically modified organisms and derived products-nucleic acid extraction (ISO/ DIS 21571) Geneva, Switzerland: International Organizations of Standards

Council for Agriculture Science and Technology (CAST). 2006. Safety of Meat, Milk, and Eggs from Animals Fed Crops Derived from Modern Biotechnology. Issue Paper 34. Ames, Iowa: CAST

Datukishvili, N., Kutateladze, T., Gabriadze, I., Bitskinashvili, K. and Vishnepolsky, B. (2015). New multiplex PCR methods for rapid screening of genetically modified organisms in foods. Frontiers in Microbiology, 6, 757-

European Commission. (1997). Regulation (EC) No. 258/97 of the European Parliament and of the Council of 27 January 1997 concerning novel foods and novel food ingredients. Official Journal L, 43, 0001-0006. 
European Commission. (1998). Council regulation (EC) No. 1139/98 of 26 May 1998 concerning the compulsory indication of the labelling of certain foodstuffs produced from genetically modified organisms of particulars other than those provided for in Directive 79/112/EC. Official Journal L, 159, 0004-0007

European Commission (2000). Commission Regulation (EC) No. 49/2000 of 10 January 2000 amending Council Regulation (EC) No. 1139/98 concerning the compulsory indication on the labelling of certain foodstuffs produced from genetically modified organisms of particulars other than those provided for in Directive 79/112/EEC. Official Journal L, 006, 0013-0014.

European Commission (2000). Commission Regulation (EC) No. 50/2000 of 10 January 2000 on the labelling of foodstuffs and food ingredients containing additives and flavourings that have been genetically modified or have been produced from genetically modified organisms. Official Journal L, 006, 0015-0017

European Commission. (2003a). Regulation (EC) No.1829/2003 of the European Parliament and of the Council of 22 September 2003 on genetically modified food and feed. Official Journal of the European Union $L, 268,1-23$.

European Commission. (2003b). Regulation (EC) No.1830/2003 of the European Parliament and of the Council of September 2003 concerning the traceability and labelling of genetically modified organisms and the traceability of food and feed product produced from genetically modified organisms and amending Directive2001/18/EC. Official Journal of the European Union L, 268, 24-28.

Friends of the Earth (May, 2006). Genetically modified animal feed. Retrieved January 5, 2017 from Friends of the Earth website: https://www.foe.co.uk/sites/ default/files/downloads/gm_animal_feeds.pdf

Gabriadze, I., Kutateladze, T., Vishnepolsky, B., Karseladze, M. and Datukishvili, N. (2014). Application of PCR-based methods for rapid detection of corn ingredients in processed foods. International Journal of Nutrition and Food Science, 3, 199-202

Gryson, N. (2010). Effect of food processing on plant DNA degradation and PCR-based GMO analysis: a review. Analytical and Bioanalytical Chemistry, 396(6), 2003-2022.

He, Q., Marjamaki, M., Soini, H., Mertsola, J. and Viljanen, M.K. (1994). Primers are decisive for sensitivity of PCR. BioTechniques, 17, 82-87.

Hemmer, W. (1997). Foods derived from genetically modified organisms and detection methods. Agency for Biosafety Research and Assessment of Technology Impacts of the Swiss Priority Program Biotechnology of the Swiss National Science Foundation, Basel, Switzerland. BATSReport 02/1997. Retrieved from http:/www.bats.ch/bats/publikationen/ 1997-2_gmo/ gmo_food.pdf
James, C. (2003). Preview: Global status of commercialized transgenic crops: 2001. ISAAA Brief No. 24. Ithaca, New York: International Service for the Acquisition of Agrobiotech Application

James, C. (2007). Global status of commercialized biotech/GM crops, 2007, Vol. 37. Ithaca Nova Yorque: International Service for the Acquisition of Agrobiotech Application.

Jasbeer, K., Ghazali, F.M., Cheah, Y.K. and Son, R. (2008). Application of DNA and Immunoassay Analytical Methods for GMO Testing in Agricultural Crops and Plant-Derived Products. ASEAN Food Journal, 15(1), $1-25$.

Kutateladze, T., Gabriadze, I., Vishnepolsky, B., Karseladze, M. and Datukishvili, N. (2013). Development of triplex PCR for simultaneous detection of maize, wheat and soybean. Food Control, $34,698-702$

Latifah Amin, Jamal Othman, Goh, H. L. and Kamaruzaman Jusoff. (2011). Consumer Information and agro-biotechnology: The experience of Malaysia. American-Eurasian Journal of Agriculture and Sciences, 1006-1017.

Malaysian Food Act 1983 and Regulations 1985. Malaysia: International Law Book Services.

Matsuoka, T., Kuribara, H., Takubo, K., Akiyama, H., Miura, H., Goda, Y., Kusakabe, Y. and Isshiki, K. (2002). Detection of recombinant DNA segments introduced to genetically modified maize (Zea mays). Journal of Agricultural and Food Chemistry, 50(7), 2100-2109.

Obrycki, J.J. Losey, J.E., Taylor, O.R. and Jesse, L.C.H. (2001). Transgenic Insecticidal Corn: Beyond Insecticidal Toxicity to Ecological Complexity. BioScience, 51(5), 353-361

Roux, K.H. (2003). Optimization and Troubleshooting in PCR. In Dieffenbach and Dveksler (Eds). PCR Primer: A Laboratory Manual. 2nd ed. New York, USA: CSHL Press

Trapmann, S., Catalani, P., Conneely, P., Corbisier, P., Gancberg, D., Hannes, E., Le Guem, L., Kramer, N., Prokisch, J., Robouch, P., Schimmel, H., Zeleny, R., Pauwels, J., Van den Eede, G., Weighardt, F., Mazzara, M. and Anklam, E. (2002). The certification of reference materials of dry mixed soya powder with different mass fraction of roundup ready TM soya. Certified reference materials IRMM-410S. European Commission: Joint Research Centre. Institute for Reference Materials and Measurement (IRMM), Geel (BE)

United States Department of Agriculture (USDA). (2000). Frequently Asked Questions. Retrieved on January 6, 2017 from USDA website: www.usda.gov/agencies/ biotech/faq.html

Van Eenennaam, A.L. and Young, A. (2014). Prevalence and impacts of genetically engineered feedstuffs on livestock populations. Journal of Animal Science, 92, $4255-4278$ 
Van Eenennaam, A.L. and Young, A.E. (March, 2016). Feeding GMO Crops to Livestock. Beef Issues Quarterly. Retrieved on January 5, 2017 from Beef Research website: http://www.beefresearch.org/ beefissuesquarterly.aspx?id=5672

Xu, J., Zhu, S., Miao, H., Huang, W., Qiu, M., Huang, Y., Fu, X. and Li, Y. (2007). Event-Specific Detection of Seven Genetically Modified Soybean and Maizes using Multiplex-PCR Couples with Oligonulceotide Microarray. Journal of Agricultural and Food Chemistry, 55(14), 5575-5579

Zimmermann, A., Luthy, J. and Pauli, U. (1998). Quantitative and qualitative evaluation of nine different extraction methods for nucleic acids on soya bean food samples. Z Lebensm Unters Forsch A, 207, 81-90. 